\title{
Психологические особенности личностной безопасности педагогов в образовательной сфере постконфликтного региона
}

Возникшие длительные две военные компании на территории Чеченской ресnублики привели к снижению уровня психологической безопасности в образовательной среде, которые по сей день нуждаются в оказании поддержки для повышения уровня комфортности педагогов, работающих в общеобразовательных школах постконфликтного региона. В связи сэтим, проведено исследование психологических особенностей педагогов из Чеченской республики.

Ключевые слова: психологическая безопасность образовательной среды, психологические особенности педагогов, благополучные и неблагополучные школы, личностные особенности, последствия войны, постконфликтный регион.

В ряде южных территорий России на рубеже XX-XXI веков произошли военные конфликты межэтнического и военно-политического характера. Оказалось нарушенным складывающееся столетиями сбалансированное сосуществование народов с разными религиями и культурами. Самым тяжелым оказался военнополитический конфликт в Чеченской республике, приведший к массовой гибели родных, близких людей, а также к массовому переселению мирныхжителей в другие местности для нахождения убежища, миграция в зарубежные государства в статусе беженцев и вынужденных переселенцев.

Война, межнациональные конфликты оставляют неизгладимый след на сознании личности. В свете произошедших событий изучение психологической безопасности педагогов, работающих в условиях постконфликтного региона, становится особенно актуальным $[1,6]$.

Возникшие военные конфликты существенно повлияли на специфику личностных особенностей педагогов общеобразовательных школ Чеченской республики в рамках участников образовательного процесса [7]. Особенно, важно, что самые глубинные проблемы возникли в образовательной системе Чеченской республики. Из-за произошедших длительных военных действий у педагогов произошла переоценка ценностей, сформировались специфические личностные особенности.

Особую необходимость в данном случае имеет изучение психологической безопасности образовательной среды Чеченской республики, ведь прошедшие две военные компании значительно повлияли на психическое здоровье всех участников образовательного процесса. Имеющийся внутренний кризис личности привел к личностным особенностям, деформациям, девиациям, нуждающимся в психологическом изучении и коррекции.

В рамках нашей работы мы изучили особенности психологической безопасности образовательной среды постконфликтного региона. 
Целью исследования является изучение психологических особенностей педагогов, работающих в школах Чеченской республики с разным уровнем психологической комфортности и безопасности.

В задачи эмпирического исследования входит:

1) провести анализ ситуации, отражающей состояние психологической безопасности образовательной среды ряда общеобразовательных школ Чеченской республики на основе результатов анкетирования;

2) выявить специфические особенности личности и факторы, оказывающие влияние на уровень психологической безопасности учителей общеобразовательных школ Чеченской республики;

3) обобщить результаты исследования, представить выводы и рекомендации.

В качестве объекта исследования выступили: педагоги начальных классов городских и сельских школ Чеченской республики в возрасте от 21 до 59 лет, средний возраст которых составляет 43 года, стаж педагогической деятельности 19,5 лет. Общий объём выборки составил 102 человека, из них - все женщины (100 \%) и учителя начальных классов городских и сельских школ Ростовской области в количестве 45 человек.

Выдвинуты следующие гипотезы исследования.

1. Работа в условиях постконфликтного региона оказывает влияние на специфику личностных проявлений и характер педагогической деятельности педагога.

2. Педагоги, получившие опыт психотравмирующих переживаний отличаются от своих коллег из относительно благополучных регионов Российской Федерации направленностью и выраженностью смысложизненных ориентаций, характером педагогического общения с учащимися.

3. Предшествующий опыт психотравмирующих переживаний личности педагога и учащихся и ведет к снижению уровня психологической безопасности образовательной среды.

4. Возможна разработка коррекционно-развивающей программы, направленной на разрешение личностных проблем педагогов, работающих в постконфликтном регионе, минимизацию негативных последствий психотравмирующих переживаний.

В соответствии с выдвинутыми целями и гипотезами в ходе исследовательской работы решалась задача выявления взаимосвязи структуры ценностных и смысложизненных ориентаций со стилем педагогического общения, характером социально-психологического климата в коллективе, уровнем выраженности конвенциально-стереотипных социальных установок педагогов и направленностью мотивации.

Процедура исследования на предварительном этапе состояла в подборе методик, наиболее приемлемых для выполнения поставленных в исследовании цели и задач. 
Учителям начальных классов городских и сельских образовательных учреждений Чеченской республики и ростовского региона и согласившимся принять участие в исследовании, в индивидуальном порядке предлагался комплект, состоящий из набора тестовых заданий.

При проведении исследовательской работы и обработки результатов использовалась комплексная методика, включающая следующие основные методы:

-анкетирование;

-опрос, состоящий из набора тестовых заданий;

- методы математической статистики (STATISTIKA 6.0).

Для данного исследования применялись следующие методики.

1. Анкета, разработанная Абакумовой И.В., Масаевой 3.В. для исследования особенностей психологической среды школ постконфликтного региона.

2. Смысложизненные ориентации (Д.А. Леонтьев).

3. Ценностные ориентации М. Рокича.

4. Методика по выявлению конвенциально-стереотипных социальных установок (А. Эллиса).

5. Опросник самоотношения (В.В.Столин)

6. Направленность личности (Б. Басс).

7. Мотивация успеха и боязнь неудачи (А.А. Реан).

8. Стиль общения в коллективе.

9. Изучение социально-психологического климата.

В проведенном исследовании получены результаты, позволившие сделать следующие выводы.

1. Изучение индивидуальной структуры ценностных ориентаций личности учителей из постконфликтного региона показало, что структура ценностных ориентаций имеет свою специфику, в которой наиболее представлены ценности личной и индивидуальной жизни. Что может свидетельствовать о наличии выраженной потребности в семейном благополучии и желании проявления себя. Данные результаты могут являться следствием пережитого в военных конфликтах и обострении именно этих базовых ценностей.

2. В отличие от двух групп учителей («благополучных» «неблагополучных») Чеченской республики выборка учителей Ростовского региона показала значимость ценности профессиональной самореализации и ценности личной жизни.

3. Насыщенность жизни и удовлетворенность самореализацией, а также внутренний локус контроля Я и жизнь наиболее (представлены) выражены у учителей из относительно благополучных регионов РФ, по сравнению с учителями из постконфликтного региона.

4. Психологические портреты учителей из «благополучных» «неблагополучных» школ (Чеченская республика) имеют некоторые различия, которые проявляются, прежде всего: в ценностных ориентациях, стиле педагогического общения, мотивационной направленности. 
5. В группе «благополучных» у испытуемых наблюдается наличие положительной прямой связи между ценностью «развитие» мотивацией достижений $(0,31)$, мотивацией на успех $(0,37)$, между творчеством и мотивацией успеха $(0,38)$. Данные результаты свидетельствуют о том, что мотивация достижений и надежда на успех в данной выборке в большей степени связывается с возможностью развития и творческой самореализации.

6. В коллективах «благополучных» школ преобладает тенденция кпозитивному общению, так в данной выборке наибольшее выражение получил стиль «Союз», который характеризуется направленностью на дружеское взаимодействие с сохранением ролевой дистанции. Возникающие учебные, организационные, этические и другие проблемы творчески решаются совместными усилиями. Что также подтверждается наличием корреляционных связей между ценностью «развитие» и стилями общения.

7. В группе «неблагополучных» альтруистические ценности и ценности принятия других (терпимость, чуткость, широта взглядов) являются незначимыми. По мнению учителей из группы «неблагополучных» успешность профессиональной и жизненной самореализации в большей степени зависит от того, что нужно в первую очередь ориентироваться на свою позицию и в меньшей степени считаться с мнением других, меньше проявлять чуткость и заботу по отношению к другим, что обобщенно это можно назвать интолерантной позицией.

8. Учителя в структуре ценностей, которых имеют место интолерантность и нетерпимость к чужому мнению, не являются гарантами психологической безопасности образовательной среды и сами часто проецируют враждебность и повышенную конфликтность в детских коллективах.

9. Изучение конвенциально-стереотипных социальных установок педагогов показало, что во всех выборках учителей наблюдаются иррациональные установки мышления по всем показателям теста.

Проведенное исследование показало, четкую разграниченность между благополучными и неблагополучными школами Чеченской республики, а также выявлены сходства и различия между школами Ростовской области и Чеченской республики. Полученные результаты свидетельствуют о необходимости создания коррекционноразвивающей программы среди педагогов Чеченской республики направленной на разрешение выявленных проблем. Для повышения уровня психологической безопасности в образовательной сфере Чечни после проведенного исследования разработаны методические рекомендации для руководителей, педагогов, психологов общеобразовательных школ республики. В данной работе предлагается несколько методик, а также алгоритм создания оптимального уровня психологической безопасности в образовательной среде постконфликтного региона.

\section{Литература}

1. Акаев В.Х. Изучение основных причин социально-психологической напряженности в Чеченской республике и выработка мер по ее терапии - актуальная 
задача социальной работы // Региональная научно-практическая конференция Южного федерального округа «Психическое здоровье населения в условиях длительной чрезвычайной ситуации»: Материалы конференции (27-28 апреля 2007 года, Грозный. - С. 19-20.

2. Баева И.А., Волкова Е.Н., Лактионова Е.Б. Психологическая безопасность образовательной среды:Учебное пособие / Под ред. И.А.Баевой - М.: Экон-Информ, 2009. - 248 c.

3. Дадаев Л.М. Доклад августовской конференции учителей 2003 г. // Вестник Института проблем образования МОиН ЧР. - Выпуск 1. - Грозный: Издательство «Аббат», 2003. - 184 c.

4. Джамулаев А.А. Подготовка педагогических кадров и формирование кадрового резерва для образовательных учреждений ЧР Вестник Института проблем образования МОиН ЧР. - Вып. 4. - Грозный: Изд-во «Абат», 2006. - С. 31-36.

5. Обеспечение психологической безопасности в образовательном учреждении: практическое руководство / Под ред. И.А. Баевой. - СПб.: Речь, 2006. - 288 с.

6. Отчет по результатам реализации совместного проекта ЮНЕСКО и Российской Федерации «Создание потенциала в сфере психологической, педагогической, медико-социальной реабилитации школьников и работников образования Чеченской республики» / Авторы В.В. Рубцов, С. Веджетти. - М: МГППУ, 2009. $68 \mathrm{c}$.

7. Социально-психологическое обследование детей Чеченской республики, получивших психические травмы в результате ведения военных действий / Грозный-Назрань-Ставрополь, 2006.

8. Экспертиза психологической безопасности образовательной среды. Информационно-методический бюллетень Городской экспериментальной площадки второго уровня / Редакторы-составители И.А. Баева, В.В. Ковров. - И.: Экон-Информ, 2009. - № 2. - 76 с. 